\title{
Examining Student Perception of Readiness for Online Learning: Importance and Confidence
}

\author{
Florence Martin, Brandy Stamper, and Claudia Flowers \\ University of North Carolina Charlotte
}

\begin{abstract}
This survey study examined student readiness for online learning in 2018 through the dimensions of importance placed by the student in online learning and the student's confidence in their ability as measures of readiness. An instrument with four subscales of competencies (online student attributes, time management, communication, and technical) that measure student readiness for online learning (SROL) was developed. Reliability of student responses on the online readiness instrument and factors related to student perception of readiness were examined. Descriptive statistics and item level means for the competencies are provided. Repeated measures analyses of variance were conducted to examine differences between participants' ratings of importance and confidence. Online student attributes, time management, and technical competencies were rated high for importance compared to communication competencies. Students were confident in online student attributes and technical competencies compared to time management and communication. Data were also analyzed based on demographic differences. MANOVA showed significant differences based on the race (white and nonwhite) of the students and course format (asynchronous, synchronous, and blended) on their perceptions of online learning competencies.
\end{abstract}

Keywords: student readiness, online learning, student attitude, student ability, student perception

Martin, F., Stamper, B., \& Flowers, C. (2020). Examining student perception of their readiness for online learning: Importance and confidence. Online Learning, 24(2), 38-58.

https://doi.org/10.24059/olj.v24i2.2053

\section{Examining Student Perception of their Readiness for Online Learning: Importance and Confidence}

Since 1990, online learning has increased with higher education institutions investing considerable resources in electronic learning technologies (Collins, McKinniees, \& Collins, 2010; Deng \& Tavares, 2013; Moore, 2013). These technologies included Learning Management Systems (LMS) to facilitate online courses and online student collaboration as well as track students' progress (Islam, 2012). From the online classroom to the utilization of polling software, digital e-books, and adaptive learning management systems, educational technology options are growing and have transformed how higher education institutions approach curriculum and 
learning engagement. Data collected from U.S. higher education institutions found that in the fall of 2015 , over six million college students $(29.7 \%$ of all higher education enrollments) were enrolled in at least one online course and, as a result, online course enrollments were increasing while the enrollment rates of physical campus courses were declining (Allen \& Seaman, 2017). As the prevalence of online course offerings in higher education increases, so does the need for research on factors contributing to students' academic success in those online environments. Online courses require students to consider new ways to prepare, organize, engage, and complete requirements calling for students to utilize higher levels of independence and self-direction. This study aimed to examine online student readiness for online learning based on students' perception of the importance of and their confidence in several competencies.

\section{Review of Relevant Literature}

\section{Student Readiness for Online Learning Instruments}

Interest in student readiness for distance education dates back to the mid-1990s when Biner, Dean, and Mellinger (1994) examined learner characteristics in televised college-level courses. The concept of student readiness for online learning was first coined by Warner, Christie, and Choy (1998). In their study, student readiness for online learning was broken down into three key facets: students' preference in course modality, student competence and confidence in utilizing computer-mediated communication, and students' ability to participate in self-directed learning. Since then, researchers have continued their efforts to measure student readiness in online learning through the creation of a number of online student readiness instruments (Bernard, Brauer, Abrami, \& Surkes, 2004; Dray \& Miszkiewicz, 2007; Kerr, Rynearson, \& Kerr, 2006; Mattice \& Dixon, 1999; McVay, 2001; Parnell \& Carraher, 2002; Watkins, Leigh, \& Triner, 2004). Student readiness has been examined over the years through a variety of constructs. Table 1 includes details about some of the information and constructs of online student readiness instruments. Farid (2014) conducted a systematic review of student online readiness assessment tools and evaluated the quality of instruments developed through ten studies between the years 2001 to 2008 . He examined 31 e-learning constructs among the 10 instruments and found that the highest number of common constructs in these instruments was seven. This illustrates the various foci among these instruments. Also, with the changing technologies and students' different levels of prior knowledge, there was a need to examine student readiness over time. By reviewing the literature, several existing online student readiness survey instruments and the constructs each instrument measured were identified (see Table 1).

\section{Student Online Readiness Surveys in Universities}

Farid (2014) surveyed 18 U.S. universities and found that many of the universities created their own self-assessment instruments to use with their students and these were not validated or published. Table 2 below is a list of some existing instruments found from a Google search. 


\section{Table 1}

Summary of Existing Online Student Readiness Survey Instruments

\begin{tabular}{|c|c|c|c|c|}
\hline $\begin{array}{l}\text { Name of } \\
\text { Instrument }\end{array}$ & Authors/Year & $\begin{array}{l}\text { Number of } \\
\text { Survey Items }\end{array}$ & Constructs Measured & Validated by \\
\hline $\begin{array}{l}\text { Distance } \\
\text { Learning } \\
\text { Survey }\end{array}$ & $\begin{array}{l}\text { Mattice and } \\
\text { Dixon (1999) }\end{array}$ & 25 items & $\begin{array}{l}\text { Student readiness, student assess } \\
\text { to/use of technology, and student } \\
\text { interest in distance education, } \\
\text { demographic questions }\end{array}$ & $\begin{array}{l}\text { Muse (2003); Osborn } \\
(2001)\end{array}$ \\
\hline $\begin{array}{l}\text { Readiness for } \\
\text { Online } \\
\text { Learning } \\
\text { (ROL) }\end{array}$ & $\begin{array}{l}\text { McVay } \\
(2000 / 2001 \\
2003)\end{array}$ & 13 items & $\begin{array}{l}\text { Self-management of learning (time } \\
\text { management and self-discipline), } \\
\text { comfort with e-learning (technical } \\
\text { skills and use of discussion } \\
\text { boards) }\end{array}$ & $\begin{array}{l}\text { Smith, Murphy, and } \\
\text { Mahoney (2003); } \\
\text { Smith (2005) }\end{array}$ \\
\hline $\begin{array}{l}\text { E-learner } \\
\text { Readiness } \\
\text { Self- } \\
\text { assessment }\end{array}$ & $\begin{array}{l}\text { Watkins, Leigh, } \\
\text { and Triner } \\
(2004)\end{array}$ & 27 items & $\begin{array}{l}\text { Technology access, online } \\
\text { relationships, motivation, online } \\
\text { video/audio, internet } \\
\text { discussions, importance to success }\end{array}$ & $\begin{array}{l}\text { Watkins, Leigh, and } \\
\text { Triner (2004) }\end{array}$ \\
\hline $\begin{array}{l}\text { Test of Online } \\
\text { Learning } \\
\text { Success } \\
\text { (TOOLS) }\end{array}$ & $\begin{array}{l}\text { Kerr, Rynearson, } \\
\text { and Kerr (2006) }\end{array}$ & 45 items & $\begin{array}{l}\text { Computer skills, independent } \\
\text { learning and dependent learning } \\
\text { preferences, need for online } \\
\text { learning, academic skills }\end{array}$ & $\begin{array}{l}\text { Kerr, Rynearson, and } \\
\text { Kerr (2006) }\end{array}$ \\
\hline $\begin{array}{l}\text { Online } \\
\text { Learning } \\
\text { Readiness } \\
\text { Survey } \\
\text { (OLRS) }\end{array}$ & $\begin{array}{l}\text { Dray and } \\
\text { Miszkiewicz } \\
(2007)\end{array}$ & 40 items & $\begin{array}{l}\text { Learner characteristics, technology } \\
\text { capabilities, online skills, self- } \\
\text { management }\end{array}$ & $\begin{array}{l}\text { Dray and } \\
\text { Miszkiewicz, (2007) }\end{array}$ \\
\hline $\begin{array}{l}\text { Online } \\
\text { Learning } \\
\text { Readiness } \\
\text { Scales (OLRS) }\end{array}$ & $\begin{array}{l}\text { Hung, Chou, } \\
\text { Chen, and Own } \\
\text { (2010) }\end{array}$ & 18 items & $\begin{array}{l}\text { Computer/internet self-efficacy, } \\
\text { online communication self- } \\
\text { efficacy, self-directed learning, } \\
\text { learner control, motivation for } \\
\text { learning }\end{array}$ & $\begin{array}{l}\text { Hung, Chou, Chen, } \\
\text { and Own }(2010)\end{array}$ \\
\hline $\begin{array}{l}\text { Questionnaire } \\
\text { for Predicting } \\
\text { Online } \\
\text { Learning } \\
\text { Achievement }\end{array}$ & $\begin{array}{l}\text { Bernard, Brauer, } \\
\text { Abrimi and } \\
\text { Surkes (2004) }\end{array}$ & 38 items & $\begin{array}{l}\text { Confidence in prerequisite skills, } \\
\text { self-direction and initiative, desire } \\
\text { for interaction beliefs about } \\
\text { distance education }\end{array}$ & Hall (2011) \\
\hline $\begin{array}{l}\text { Student Online } \\
\text { Learning } \\
\text { Readiness } \\
\text { (SOLR) }\end{array}$ & $\begin{array}{l}\text { Yu and } \\
\text { Richardson } \\
(2015)\end{array}$ & 20 items & $\begin{array}{l}\text { Social competencies with the } \\
\text { instructor, communication } \\
\text { competencies, social competencies } \\
\text { with classmates, and technical } \\
\text { competencies) }\end{array}$ & $\begin{array}{l}\text { Yu and Richardson, } \\
\text { (2015); Yu (2018) }\end{array}$ \\
\hline $\begin{array}{l}\text { Online } \\
\text { Learning Self- } \\
\text { Efficacy scale } \\
\text { (OLSES) }\end{array}$ & $\begin{array}{l}\text { Zimmerman and } \\
\text { Kulikowich } \\
(2016)\end{array}$ & 22 items & $\begin{array}{l}\text { Learning in the online } \\
\text { environment, time management, } \\
\text { technology use }\end{array}$ & $\begin{array}{l}\text { Zimmerman and } \\
\text { Kulikowich, (2016) }\end{array}$ \\
\hline
\end{tabular}


Table 2

Student Online Readiness Instruments from Various Universities

\begin{tabular}{|c|c|c|c|}
\hline University & $\begin{array}{l}\text { Readiness } \\
\text { Instrument }\end{array}$ & Constructs & URL \\
\hline $\begin{array}{l}\text { Penn State } \\
\text { University }\end{array}$ & $\begin{array}{l}\text { Online Readiness } \\
\text { Questionnaire }\end{array}$ & $\begin{array}{l}\text { Self-Direction, Learning } \\
\text { Preferences, Study Habits, } \\
\text { Technology Skills. Computer } \\
\text { Equipment Capabilities }\end{array}$ & $\begin{array}{l}\text { http://tutorials.istudy.psu.edu/learning } \\
\text { online/ORQ/ORQ.htm }\end{array}$ \\
\hline $\begin{array}{l}\text { University } \\
\text { of Arkansas } \\
\text { Online }\end{array}$ & $\begin{array}{l}\text { Online Course } \\
\text { Readiness Quiz }\end{array}$ & $\begin{array}{l}\text { Computer Skills, Learning } \\
\text { Style, Online Learning, } \\
\text { Academic Skills }\end{array}$ & https://online.uark.edu/students/readiness-quiz.php \\
\hline $\begin{array}{l}\text { University } \\
\text { of Hawai'i } \\
\text { W'Ohau }\end{array}$ & $\begin{array}{l}\text { Student Online } \\
\text { Readiness Quiz }\end{array}$ & $\begin{array}{l}\text { Technology skills and access. } \\
\text { Time management }\end{array}$ & $\begin{array}{l}\text { https://westoahu.hawaii.edu/distancelearning/student/stu } \\
\text { dent-online-readiness-quiz/ }\end{array}$ \\
\hline $\begin{array}{l}\text { University } \\
\text { of Illinois } \\
\text { Springfield }\end{array}$ & $\begin{array}{l}\text { Are you Ready to } \\
\text { be an Online } \\
\text { Learner? }\end{array}$ & $\begin{array}{l}\text { Self-direction, Learning } \\
\text { Preferences, Study Habits, } \\
\text { Technology Skills, Computer } \\
\text { Equipment Capabilities, } \\
\text { Online Learning Awareness }\end{array}$ & https://www.uis.edu/online/ready-for-online/ \\
\hline $\begin{array}{l}\text { California } \\
\text { State } \\
\text { University } \\
\text { Stanislaus }\end{array}$ & $\begin{array}{l}\text { Online Readiness } \\
\text { Self-Assessment }\end{array}$ & No construct & $\begin{array}{l}\text { http://www.csustan.edu/academics/online- } \\
\text { programs/online-readiness-self-assessment }\end{array}$ \\
\hline $\begin{array}{l}\text { Wichita } \\
\text { State } \\
\text { University }\end{array}$ & $\begin{array}{l}\text { Online Readiness } \\
\text { Self-Assessment }\end{array}$ & No Construct & $\begin{array}{l}\text { https://www.wichita.edu/services/mrc/elearning/online } \\
\text { orientation/online self_assessment.php }\end{array}$ \\
\hline $\begin{array}{l}\text { Colorado } \\
\text { Community } \\
\text { Colleges } \\
\text { Online }\end{array}$ & $\begin{array}{l}\text { Online Learning } \\
\text { Readiness } \\
\text { Survey }\end{array}$ & No Construct & https://www.ccconline.org/survey-copy/ \\
\hline $\begin{array}{l}\text { North } \\
\text { Carolina } \\
\text { Community } \\
\text { College } \\
\text { Virtual } \\
\text { Learning }\end{array}$ & $\begin{array}{l}\text { Online Readiness } \\
\text { Assessment }\end{array}$ & $\begin{array}{l}\text { Study Habits/ Course } \\
\text { Participation \& Interaction, } \\
\text { Technology Access \& } \\
\text { Computer Skills, Time } \\
\text { Management/ Personal } \\
\text { Commitment/ Motivation }\end{array}$ & $\begin{array}{l}\text { http://vlc.nccommunitycolleges.edu/faculty/online- } \\
\text { readiness-checklist/ }\end{array}$ \\
\hline
\end{tabular}

Based on the review of instruments and surveys, four common constructs emerged: online student attributes, time management, technical, and communication competencies (Bernard, Brauer, Abrami, \& Surkes, 2004; Dray \& Miszkiewicz, 2007; Kerr, Rynearson, \& Kerr, 2006; Mattice \& Dixon, 1999; McVay, 2001; Parnell \& Carraher, 2002; Watkins et al., 2004). Figure 1 below includes the four constructs of student readiness. 


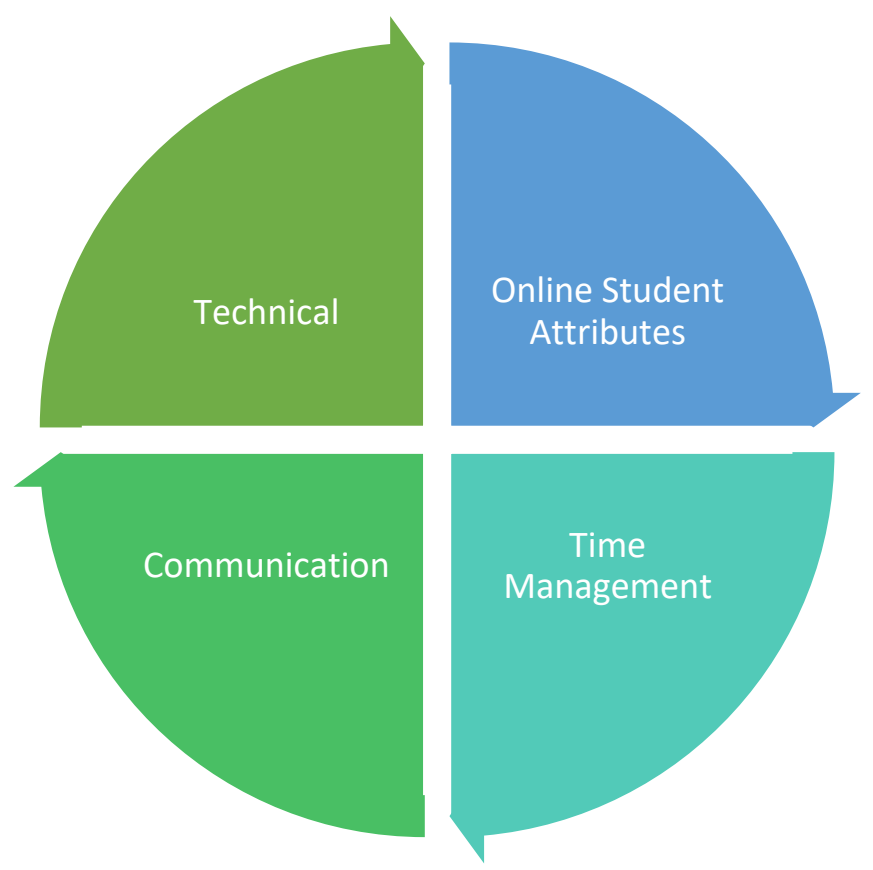

Figure 1. Student Readiness for Online Learning (SROL) Competencies.

\section{Online Student Attributes}

Researchers have attributed self-regulated learning, self-directed learning, locus of control, and academic self-efficacy as student-related factors that play an important role in student performance and readiness in online learning. Lin and Hsieh (2001) suggested that successful online learners develop higher levels of learner control, or self-directed learning, by taking responsibility for learning through self-discipline in their studies. Researchers focusing on academic locus of control have indicated that online students who have an internal locus of control tend to have higher levels of self-motivation and self-direction (Chang \& Ho, 2009; Liu, Lavelle \& Andris, 2002). Alternatively, academic self-efficacy is emphasized as an internal factor pertinent to student preparedness for online learning. The literature indicates that academic self-efficacy affects academic persistence, performance, and motivation (Caprara, Vecchione, Alessandri, Gerbino \& Barbaranelli, 2011; Gore, 2006). The McVay instrument, revised in 2004, highlights self-direction (such as utilizing resources for learning and studying), initiative, and desire for interaction (like using resources to communicate with faculty and peers) as a driving factor in student success for online learning. Zimmerman and Kulikowich's (2016) OLSES contains items relating to online student attributes such as developing and following goals to complete assigned work, being self-disciplined with their coursework, learning new technologies, and utilizing resources when questions arise. The second-dimension researchers have noted that time management is essential to online learning.

\section{Time Management Competencies}

Many researchers have linked self-management in learning as a factor associated with student preparedness for online learning (McVay, 2001; Smith et al., 2003; Smith, 2005, Zimmerman \& Kulikowich, 2016). One of the characteristics included in the self-management 
factor consists of the ability of learners to manage their time well (Smith, 2001). Time management challenges such as being able to keep up with course assignments (Roper, 2007), completing the assigned work on time (Discenza, Howard, \& Schenk, 2002), as well as actively participating in the online instruction of the class (Garrison, Cleveland-Innes, \& Fung, 2004) have been noted in the literature. Unlike face-to-face courses where there are set meeting times, students participate in asynchronous online courses on their own time and this can be a challenge if they do not possess self-discipline. Some online learning readiness scales have included time management items such as managing time effectively, meeting deadlines with very few reminders (Zimmerman \& Kulikowich, 2016), managing study time to easily complete assignments (McVay, 2001), as well as including time management as a component of self-directed learning (Hung, Chou, Chen \& Own, 2010). Another dimension researchers have identified as essential to online learning involves technical competencies in online courses.

\section{Technical Competencies}

Research on self-efficacy in the online environment emphasizes the role of technological aspects, such as computer skills, internet skills, and information-seeking skills (Cho \& Shen, 2013; McGhee, 2010; Shi, Chen \& Tian, 2011; Wang and Newlin, 2002). Boyd (2004) reported that technical skills such as sending and receiving emails, researching and downloading information online, and installing software were indicators associated with successful online students. Tsai and Tsai (2003) found that students with high internet self-efficacy demonstrated higher levels of learning in web-based tasks than low internet self-efficacy students. Additionally, the perceived quality of an online learning system, such as ease of use and quality of resources, was considered an essential factor in successful online learning (Ho, Tsung-Hsien, \& Binshan, 2010, Park \& Wentling, 2007). The online learning readiness scale (OLRS) developed by Hung et al. (2010) examined elements of computer/internet self-efficacy, online communication self-efficacy, selfdirected learning, learner control, and motivation for learning. In regard to computer/internet and online communication self-efficacy, Hung et al. (2010) survey items looked at confidence in basic computer operations, navigation of course management software, and use of online tools for course communication. Zimmerman and Kulikowich's (2016) OLSES contain items on navigating the online grade book and course materials like the online help desk. Course communication is the final dimension researchers have pointed out as essential to readiness in online learning.

\section{Communication Competencies}

Numerous researchers have identified comfort with online learning as a component of student preparedness for online learning (McVay, 2001; Smith et al., 2003; Smith, 2005). Comfort in online learning is defined by McVay (2001) and Smith (2005) as the student's willingness to connect and communicate with others via computer-mediated communication like email, discussion boards, and chat as well as confidence in accessing these resources. McKavanagh, Kanes, Beven, Cunningham, and Choy (2002) reported that a student's willingness to participate in online discussion boards was critical to the effectiveness of online learning. Online classrooms provide a multitude of asynchronous and synchronous communication tools used to facilitate communication between teachers and students. These tools range from discussion forums and email to WebEx meetings and live chat (Hew \& Cheung, 2008).

Moreover, Kaymak and Horzum (2013) noted that as communication interactions increased in the online classroom, the probabilities that students fulfill their individual learning needs also increased. The findings indicated that online communication and readiness for online 
learning were positively associated. The OLRS examines elements of online communication selfefficacy through survey items relating to comfort in using asynchronous technologies such as email and posting questions via discussion forums. On the other hand, the OLSES examines synchronous technologies for course communication.

\section{Online Student Demographics}

Few researchers have examined demographics of online students. Studies have found that fully online students tend to be older (Johnson, 2019; Ke, 2010; Kummerow, Miller \& Reed, 2012) and more often female than male (Ke \& Xie, 2009; Quinn, 2011) than those students who take a mixture of online and face-to-face courses. Colorado and Eberle (2010) found that age of the online learner affected their self-regulated learning. Cigdem and Yildirim (2014) found that students' prior experience in web-based education and access to a home computer impacted their online learning readiness at a vocational school in Turkey. Fogerson (2005), when examining online readiness factors, observed that prior online course experience and computer-related experience predicted student confidence in online learning. Johnson (2019) compared on-campus and fullyonline students and found that on-campus students were more likely to chat or tweet using a computer and also had higher extrinsic motivation for achievement.

\section{Student Readiness Conceptual Framework for Online Learning}

Existing online student readiness instruments focus on specific learner competencies ranging from technical, self-directed learning, and communication. Yet, researchers have not examined the relationship between an online student's perception of importance and confidence in their ability and online course readiness. In fact, the relationship between attitude of importance and confidence in abilities has been examined through a variety of other contexts. Rollnick, Mason, and Butler (1999) studied the relationship between the attitude of importance and confidence in ability towards readiness in health behavior change. Within the context of the current study, two aspects are focused on: (a) students' attitude on the importance of student competencies in their online learning and (b) students' perception of their confidence in their abilities to accomplish online student competencies.

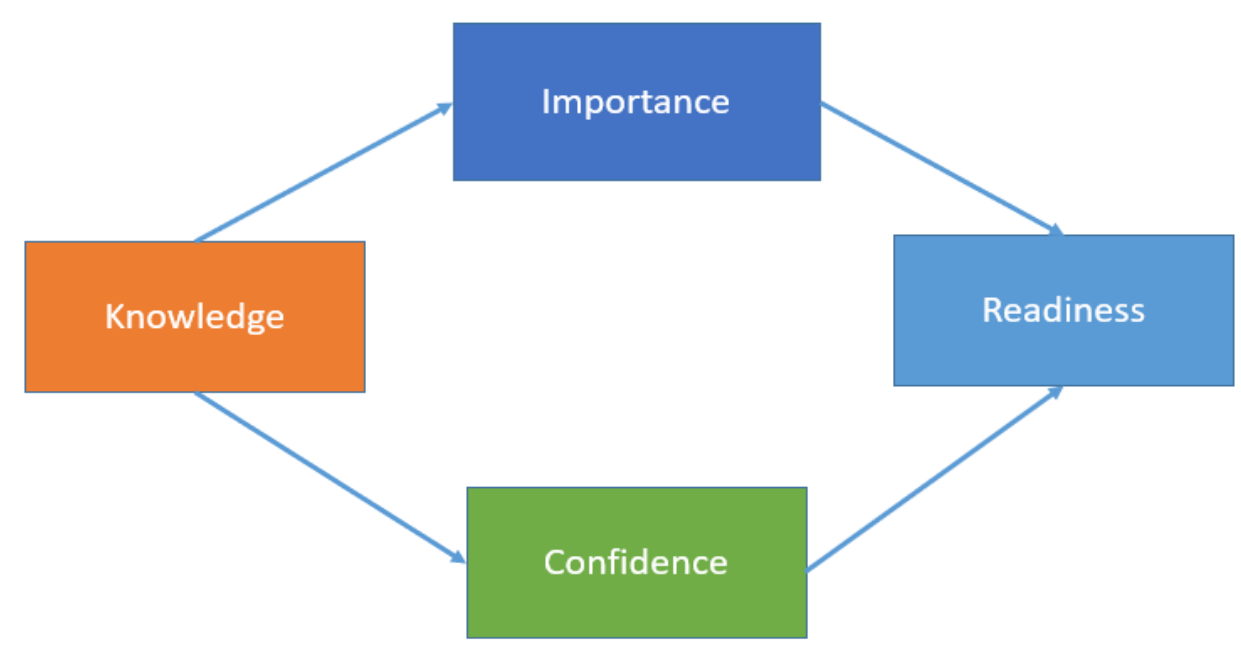

Figure 2. Conceptual Framework for Student Readiness for Online Learning (adapted from Rollnick, Mason and Butler, 1999, p. 23). 


\section{Purpose of this Study}

There is a lack of consistency among existing student readiness for online learning instruments and surveys both from published and unpublished sources. Online learning is no longer an innovation but has become the norm in majority of the universities in the U.S. In addition, though several studies on online student readiness have been conducted, it is essential for studies to examine this over time because technology has changed the way online courses are offered and students are being exposed to online learning very early in their education these days. The purpose of this study was to examine student readiness for online learning in 2018 and to propose an instrument that can be used both by researchers and universities. The Research Questions were:

1. What competencies do students consider as important for their readiness for online learning?

2. What are student perceptions of their confidence in their readiness for online learning?

3. What demographic factors are related to student perception on their readiness for online learning?

\section{Methods}

\section{Participants}

The IRB approval for distributing this survey was obtained at the researchers' institution. The survey was distributed through SurveyShare electronic survey administration tool to the Distance Education email list of students at a Southeastern University (111 respondents) and to six program directors outside this university who manage online programs (66 respondents). This was done to reach more students across the U.S. Both of the respondent pools constitute a convenience sample. In total, 177 responses were received. There was not a statistically significant difference $(p<.05)$ on any of the perception of readiness measures between the Southeastern University and students recruited through the program directors. Therefore, both samples were combined for all data analyses.

Student demographic characteristics are reported in Table 3. The average age of respondents was 37 years old and most of the respondents were female (79\%). The academic standing of respondents was master's level (24\%), seniors $(22 \%)$, and juniors $(20 \%)$. The majority of respondents attended courses using an asynchronous mode of delivery (59\%). Not quite half of the respondents were in the discipline of education (45\%), followed by health science $(20 \%)$ and liberal arts (19\%). At the time of the survey, on an average respondents had taken approximately nine courses online. 
Table 3

Student demographic characteristics $(N=177)$

\begin{tabular}{llc}
\hline Variables & & $\begin{array}{c}\text { Mean/Frequency } \\
\text { and (Percentage) }\end{array}$ \\
\hline Age & & Mean $=36.68$ \\
Gender & SD $=11.73$ \\
& Male & $138(78.9 \%)$ \\
& Freshman & $34(19.2 \%)$ \\
& Sophomore & $4(2.3 \%)$ \\
Academic & Junior & $36(1.7 \%)$ \\
Standing & Senior & $39(22 \%)$ \\
& Postbac & $4(2.3 \%)$ \\
& Grad Cert & $24(13.6 \%)$ \\
& Master & $43(24.3 \%)$ \\
& Doctoral & $7(4 \%)$ \\
Course Format & Postdoc & $7(4 \%)$ \\
& Asynchronous & $101(58.7 \%)$ \\
& Synchronous & $43(25 \%)$ \\
& Hybrid & $28(16.3 \%)$ \\
& Liberal arts & $33(18.6 \%)$ \\
Discipline & Arts \& & $1(0.6 \%)$ \\
& Architecture & $14(7.9 \%)$ \\
& Business & $80(45.2 \%)$ \\
& Education & $5(2.8 \%)$ \\
Number of & Engineering & $35(19.8 \%)$ \\
\hline & Health Sciences & Mean $=8.78$ \\
& & SD $=7.86$ \\
\hline
\end{tabular}

Note. Due to missing demographic data, not all frequencies add up to 177.

\section{Instrument}

The Student Readiness for Online Learning (SROL) instrument was developed for this study after reviewing the literature and existing student readiness instruments and surveys. Several steps were used to develop the SROL. First the subscale definitions were determined by using previous research. Zimmerman's OLSES instrument and UNC Chapel Hill Student Readiness Survey were referenced during development of the SROL. The OLSES instrument contained 25 items but did not categorize items into competencies. But some of the OLSES items addressed aspects of student attributes, communication, and time management. Though this instrument did not include all the items that captured student readiness, the detailed process of review and evaluation of items led to the creation of categories as well as specific items. Similarly, the UNC Chapel Hill instrument had similar categories of technical and self-direction competencies. This survey is no longer available to the public. Next, using these three instruments, items that aligned to the research questions of interest but were not already included were generated. 
After the items were developed, an expert review rubric was used to receive feedback from the experts. The Validation Rubric for Expert Panel (VREP) was designed to measure face validity, construct validity, and content validity and was used to receive feedback from experts (Simon \& White, 2013). This rubric included items on clarity, wordiness, negative wording, overlapping responses, balance, use of jargon, appropriateness of responses listed, use of technical language, application to practice and relationship to the problem. The new instrument and review rubric were sent to four online learning experts to identify face and content validity. The experts agreed on the categories but suggested rewording some items for clarification.

The 20 items were organized into four subscales: (a) online student attributes (5 items), (b) time management (5 items), (c) communication (5 items), and (d) technical (5 items). The items can be seen in Table 4. Participants rate each item twice, once for importance of online readiness competencies and once for confidence in their readiness for online learning, which resulted in 40 responses and eight subscales. For the importance ratings, the students were asked, "Rate how important these competencies are for you in your online learning" on a 5-point Likert scale from 1 (not important at all), 2 (unimportant), 3 (neither important or unimportant), 4 (somewhat important), to 5 (very important). In the section for confidence, respondents were asked to "Rate your confidence in your ability to accomplish the following competencies in online learning" on a 5-point Likert scale from 1 (very unconfident), 2 (somewhat unconfident), 3 (neither confident or unconfident), 4 (somewhat confident), to 5 (very confident).

Cronbach alphas for each of the eight subscales suggested reasonable internal consistency, ranging from .88 to .95 (see Table 4). A confirmatory factor analysis (CFA) was conducted to determine if evidence supported reporting results by the eight factors. The results of the CFA suggested a marginal fit of the empirical data to the eight hypothesized factors $\left(\chi_{(702)}=1319.43, p\right.$ $<.001 ; \mathrm{RMSEA}=.07$; CFI $=.91 ; \mathrm{SRMR}=.01$ ). All path coefficients between the items and the aligned factor were statistically significant. While the results of the CFA should be interpreted with caution due to the small sample size, it was determined that there was enough evidence to support using the eight subscale scores in this study.

\section{Data Analytical Procedure}

Descriptive statistics (means and standard deviations) are reported both at the item level, at the subscale level, and also by various demographic factors to address the first and second research questions. Two repeated measures ANOVAs for importance and confidence were conducted to examine differences between the four subscales. Multivariate analysis of variance (MANOVA) was employed to examine the differences among students in their responses to the survey when the characteristic was categorical (e.g., gender, academic standing). This assisted in addressing the third research question. Correlation coefficients were calculated to examine the relationship between respondents' characteristics that are continuous in nature (e.g., age) and perception of importance and confidence for online learning. 


\section{Results}

\section{Student Perception on the Importance and Confidence of Online Learning Competencies}

To examine research questions 1 and 2, the means and standard deviations by item within each of the subscales, online course attributes, time management, communication, and technical competence rated on importance and confidence are reported in Table 4 . All the means were above 4.0 except for the importance of the use of synchronous technologies, which was 3.95. This suggested that on average, respondents reported that all the competencies except for synchronous technologies were somewhat important to very important and respondents were somewhat confident to very confident in their ability to accomplish the competencies in online learning.

Two repeated measures ANOVAs for importance and confidence were used to determine differences between the subscales. For the four importance subscales, there was a statistically significant difference between the subscales (Wilks' Lambda $=.61, F=36.51, p<.001$, partial eta squared $=.39)$. Post hoc analyses indicated that respondents rated communication lower $(M=$ 4.22) than the other three subscales on importance (ranging from 4.56 for technical competency to 4.63 for time management). There was also a statistically significant difference among the four confidence subscales (Wilks' Lambda $=.76, F=17.75, p<.001$, partial eta squared $=.24$ ). Post hoc analysis indicated that respondents were the most confident in the online student attributes $(M$ $=4.54)$ and technical domains $(M=4.63)$ than the time management $(M=4.40)$ and communication domains $(M=4.33)$.

Table 4

Student Readiness in Online Learning Descriptive Statistics

Student Readiness Online Learning Competencies

\section{Online Student Attributes}

1 Set goals with deadlines

2 Be self-disciplined with studies

3 Learn from a variety of formats (lectures, videos, podcasts, online discussion/conferencing).

4

Be capable of following instructions in various formats

(written, video, audio, etc.)

Utilize additional resources to answer course-related

questions (course content, assignments, etc.)

Mean (SD)

Reliability

Time Management

6 Devote hours per week regularly for the online class

7 Stay on task and avoid distractions while studying

8 Utilize course schedule for due dates

9 Complete course activities/assignments on time

10 Meeting multiple deadlines for course activities

Mean (SD)

Reliability

$4.51(1.01)$
$4.42(0.99)$
$4.71(0.84)$
$4.80(0.84)$
$4.76(0.82)$
$\mathbf{4 . 6 3 ( 0 . 8 4 )}$
$\mathbf{. 9 5}$

$4.23(1.10)$

$4.02(1.09)$

$4.72(0.77)$

$4.58(0.96)$

$4.51(0.97)$

$4.40(0.88)$

.92
$4.58(0.80)$

$4.52(0.87)$

$4.52(0.91)$

$4.58(0.88)$

$4.55(0.87)$

$4.54(0.79)$

.93 
Table 4 (continued)

Student Readiness in Online Learning Descriptive Statistics

\begin{tabular}{lcc}
\hline \multicolumn{1}{c}{ Student Readiness Online Learning Competencies } & $\begin{array}{c}\text { Importance } \\
\text { M(SD) }\end{array}$ & $\begin{array}{c}\text { Confidence } \\
\text { M(SD) }\end{array}$ \\
\hline $\begin{array}{l}\text { Communication } \\
\begin{array}{l}\text { Use asynchronous technologies (discussion boards, email, } \\
\text { etc.) }\end{array}\end{array}$ & $4.47(0.97)$ & $4.63(0.80)$ \\
$\begin{array}{l}\text { Use synchronous technologies (Webex, Collaborate, } \\
\text { Adobe Connect, Zoom, etc.) to communicate }\end{array}$ & $3.95(1.05)$ & $4.15(1.12)$ \\
$\begin{array}{l}\text { Ask the instructor for help via email, discussion board, or } \\
\text { chat. }\end{array}$ & $4.48(0.96)$ & $4.49(0.96)$ \\
$\begin{array}{l}\text { Ask classmates for support (accessing the course, } \\
\text { clarification on a topic) }\end{array}$ & $4.02(1.06)$ & $4.07(1.15)$ \\
$\begin{array}{l}\text { Discuss feedback received (assignments, quizzes, } \\
\text { discussion, etc.) with the instructor } \\
\text { Mean (SD) }\end{array}$ & $4.21(1.05)$ & $4.35(0.99)$ \\
Reliability
\end{tabular}

\section{Technical Competence}

Complete basic computer operations (e.g., creating and editing documents, managing files, and folders) System (e.g., Moodle, Canvas, Blackboard, etc.) assignments. synchronous sessions) 19 Access the online grade book for feedback on performance

$4.72(0.86)$

\section{Demographic Factors and Student Perception of Importance and Confidence in Competencies for Online Learning}

The following analyses examined differences and relationships of perception of importance and confidence for online learning by respondents' characteristics and course format. Specifically, differences were examined based on gender, undergraduate/graduate status, academic major (education degree compared to a non-education degree), race (white compared to non-white), age, number of online courses, and course format. Because there were multiple correlated outcome variables, MANOVAs were used to examine difference when the characteristic was categorical (e.g., gender, academic standing, race, academic discipline, and course format). Correlation coefficients were calculated to examine the relationship between respondents' characteristics that are continuous in nature (e.g., age, number of online courses), and perception of importance of online readiness competencies and confidence in their readiness for online learning. The means by student characteristics are provided in Table 5. 
Table 5

Student Readiness by Demographics

\begin{tabular}{|c|c|c|c|c|c|c|c|c|}
\hline & \multicolumn{4}{|c|}{ Importance } & \multicolumn{4}{|c|}{ Competence } \\
\hline & $\begin{array}{l}\text { Course } \\
\text { Design } \\
\mathrm{M}(\mathrm{SD}) \\
\end{array}$ & $\begin{array}{l}\text { Course } \\
\text { Communication } \\
\mathrm{M}(\mathrm{SD})\end{array}$ & $\begin{array}{l}\text { Time } \\
\text { Management } \\
\text { M (SD) }\end{array}$ & $\begin{array}{l}\text { Technical } \\
\text { Competence } \\
\mathrm{M} \text { (SD) }\end{array}$ & $\begin{array}{l}\text { Course } \\
\text { Design } \\
\mathrm{M}(\mathrm{SD}) \\
\end{array}$ & $\begin{array}{l}\text { Course } \\
\text { Communication } \\
\mathrm{M}(\mathrm{SD}) \\
\end{array}$ & $\begin{array}{l}\text { Time } \\
\text { Management } \\
\mathrm{M}(\mathrm{SD})\end{array}$ & $\begin{array}{l}\text { Technical } \\
\text { Competence } \\
\mathrm{M} \text { (SD) }\end{array}$ \\
\hline \multicolumn{9}{|l|}{ Gender } \\
\hline Female $(\mathrm{N}=137)$ & $4.57(.92)$ & $4.61(.94)$ & $4.21(.90)$ & $4.55(.89)$ & $4.47(.87)$ & $4.35(.96)$ & $4.28(.91)$ & $4.58(.80)$ \\
\hline Male $(\mathrm{N}=34)$ & $4.66(.37)$ & $4.71(.37)$ & $4.21(.65)$ & $4.58(.36)$ & $4.75(.35)$ & $4.58(.45)$ & $4.49(.58)$ & $4.81(.32)$ \\
\hline \multicolumn{9}{|l|}{ Academic Standing } \\
\hline Undergraduate & $4.60(.88)$ & $4.63(.87)$ & $4.17(.93)$ & $4.55(.86)$ & $4.38(.92)$ & $4.31(.100)$ & $4.18(.95)$ & $4.60(.76)$ \\
\hline Graduate & $4.61(.74)$ & $4.64(.77)$ & $4.29(.74)$ & $4.59(.70)$ & $4.66(.65)$ & $4.49(.75)$ & $4.47(.75)$ & $4.65(.70)$ \\
\hline \multicolumn{9}{|l|}{ Race } \\
\hline White & $4.62(.75)$ & $4.65(.76)$ & $4.14(.81)$ & $4.55(.74)$ & $4.60(.70)$ & $4.43(.79)$ & $4.35(.76)$ & $4.70(.56)$ \\
\hline Non-White & $4.56(.99)$ & $4.59(1.00)$ & $4.37(.91)$ & $4.57(.94)$ & $4.40(.95)$ & $4.32(.104)$ & $4.27(.102)$ & $4.48(.97)$ \\
\hline \multicolumn{9}{|l|}{ Academic Discipline } \\
\hline Education & $4.67(.64)$ & $4.68(.67)$ & $4.36(.63)$ & $4.64(.58)$ & $4.69(.55)$ & $4.51(.69)$ & $4.54(.61)$ & $4.71(.56)$ \\
\hline Non-Education & $4.61(.85)$ & $4.65(.85)$ & $4.17(.89)$ & $4.55(.84)$ & $4.49(.81)$ & $4.41(.86)$ & $4.24(.88)$ & $4.64(.66)$ \\
\hline $\begin{array}{l}\text { Course Format } \\
\text { Asynchronous }\end{array}$ & \multicolumn{7}{|c|}{ Course Format } & $4.58(.86)$ \\
\hline Synchronous & $4.57(.88)$ & $4.61(.85)$ & $4.18(.89)$ & $4.57(.86)$ & $4.53(.7)$ & $4.47(.82)$ & $4.2(.84)$ & $4.63(.53)$ \\
\hline Blended & $\begin{array}{c}4.49 \\
(1.03)\end{array}$ & $4.42(1.06)$ & $4.1(1.1)$ & $4.42(1.03)$ & $4.75(.36)$ & 4.38 (.6) & $4.61(.71)$ & $4.79(.4)$ \\
\hline
\end{tabular}

Gender. Across all the measures, responses from males were higher than females, but there was not a statistically significant difference between females and males on the perception of importance of online readiness competencies and confidence in their readiness for online learning (Wilks' Lambda $=.97, F_{(8,161)}=.62, p=.76$, partial eta squared $\left.=.03\right)$. Caution should be made in interpreting these results because of the small number of males in the study $(N=34)$.

Undergraduate and Graduate Status. Across all the measures, graduate students reported higher means than undergraduate students, but there was not a statistically significant difference between undergraduates and graduate student respondents on the perception of importance of online readiness competencies and confidence in their readiness for online learning $\left(\right.$ Wilks' Lambda $=.91, F_{(8,157)}=1.86, p=.07$, partial eta squared $\left.=.09\right)$.

Education and Non-education Majors. There was not a statistically significant difference between education majors and non-education majors on the perception of importance of online readiness competencies and confidence in their readiness for online learning (Wilks' Lambda $=$ $.93, F_{(8,157)}=1.55, p=.14$, partial eta squared $\left.=.07\right)$.

White and Non-white Students. There was a statistically significant difference between white and non-white student respondents on the perception of importance of online readiness competencies and confidence in their readiness for online learning (Wilks' Lambda $=.88, F_{(8,164)}$ $=2.85, p<.01$, partial eta squared $=.12$ ). Post hoc discriminant analysis suggested that white respondents rated their competencies in online student attributes and technology higher than non- 
white respondents, but non-white respondents rated the importance of communication higher than white respondents did.

Course Format. There was a difference between asynchronous, synchronous, and blended mode of course delivery (Wilks' Lambda $=.85, F_{(16,322)}=1.70, p=.05$, partial eta squared $=.08$ ). Post hoc discriminant analysis suggested that blended format students rated their competencies in online student attributes and communication higher than the asynchronous or synchronous students did.

Age. Pearson product-moment correlation coefficients were estimated between respondents' age and the eight measures of perception of importance and confidence for online learning. All correlation coefficients were not statistically significant and ranged from .04 to .145, except for confidence in communication $(r=.19, p=.01)$.

Number of Online Courses. Pearson product-moment correlation coefficients were estimated between the number of online courses taken and the eight measures of perception of importance and confidence for online learning. Seven of the eight correlation coefficients were not statistically significant with values ranging from -.05 to .15 . Only the correlation between competency in time management and number of online courses taken was statistically significant $(\mathrm{r}=.20, \mathrm{p}=.01)$.

\section{Discussion}

The findings from this study on four constructs of online learning readiness (online student attributes, time management, communication, and technical) are discussed within the two dimensions, Importance and Confidence.

\section{Importance of Online Readiness Competencies}

High ratings on most of the competencies. The categorical means for student responses on most of the items for the importance category of competencies were above 4.50. The competencies were rated between somewhat important and very important, which signifies the importance of these competencies for online learning. Most of the students are taking online courses at the university level, and not for the first time. They are coming prepared for online learning in higher education by taking online courses in middle and high schools (Toppin \& Toppin, 2015). In 2018, students rated the online readiness competencies as important as they realize the value of these competencies. Yu (2018) had similar high ratings on three of the subscales in the Student Online Learning Readiness (SOLR) instrument but had low ratings on the social competencies with classmates. Similarly, Zimmerman and Kulikowich (2016) found that students rated items on the Online Learning Self-Efficacy Scale (OLSES) high when they had online course experience compared to the students who did not.

Low ratings on communication competencies. Online student attributes, time management, and technical competencies were rated high in importance. Overall, there was a statistically significant difference in the subscales based on importance. The communication competencies were rated lower by the students compared to the other three subscales. This shows that the students value their online student attributes, their time management, and technical skills to be more important than communication skills. Only two of the previous instruments examined included a subscale on communication. Hung, Chou, Chen, and Own (2010) in the OLRS examined elements of online communication self-efficacy in using asynchronous technologies 
such as email and posting questions via discussion forums. They found that students in Taiwan rated communication competencies to be moderately high compared to self-directed learning and learner control competencies among undergraduate college students. Zimmerman and Kulikowich (2016) in the OLSES had items on communicating with the instructor, with technical support, asynchronous and synchronous communication and found these items to be rated moderately high. Both these scales did not include items on communicating with peers for course communication, which was also used in this study.

Using synchronous technologies. "Use synchronous technologies to communicate," a competency in the communication subscale, was the lowest rated competency. Though this competency was the only one rated in the $3 \mathrm{~s}$, it was still close to the rating "important." Martin and Parker (2014) found that instructors used synchronous tools to promote interaction, build a sense of community, and provide an opportunity for students from different locations to be able to participate; however, recent studies have found that students prefer the flexibility to participate asynchronously and not having to set aside specific times for online learning. Martin, Wang, and Sadaf (2018) found that students rated the use of synchronous tools to be a not very helpful facilitation strategy. In an earlier study, Park and Bonk (2007) found that the students viewed time constraints, lack of reflection, language barriers, tool-related problems, and peers' network connection problems as challenges for synchronous learning.

Ask classmates for support. "Ask classmates for support" was another competency in the communication subscale that was rated low. Students in online courses usually participate in courses from different locations and sometimes do not have the opportunity to meet or talk to their peers. Some online courses are designed without room for interaction both with the instructor and with their peers and students do not see the need to communicate or ask their classmates for support. This competency refers to the social aspect of the course and previous research has found this to be rated low. Yu (2018) found that undergraduates rated social competencies with classmates the lowest.

\section{Confidence in the Online Readiness Competencies}

High ratings on most of the competencies. Though not as high as the importance category, students still rated most of the competencies high based on confidence in their abilities. Similar to their perception of importance, students in the year 2018 were being exposed to several online courses both in middle and high school and in higher education and are confident in their skills for online learning (Toppin \& Toppin, 2015). Mazanov, Meacheam, Heaslip, and Hanson (2016) found that self-efficacy that describes students' confidence had positive effects on peer engagement, learning management system (LMS) interaction, and convener interaction on business college students.

High rating on "Online student attributes" and "Technical competencies" There was a statistically significant difference in the subscales based on confidence. The students rated the online student attributes and technical competencies higher compared to communication and time management competencies. While student attributes and technical skills might be similar for webenhanced or blended and online courses, communication and time management competencies are different (Martin \& Bolliger, 2018). Students might have rated these high as they are prepared for these tasks of online learning through prior experience. Time management in online courses is very different and students are expected to be self-disciplined learners who manage their time well. 
Similarly, communication in the online environment is different than the face-to-face communication.

Low ratings on "Stay on task" and "Avoid distractions while studying" The lowest time management competency was "stay on task and avoid distractions while studying." While time is a challenge even to the student taking a traditional on-campus course, it is even more challenging in the online environment as students have to be self-disciplined, manage their schedule, and stay on task to participate in the online course (Michinov, Brunot, Le Bohec, Juhel, \& Delaval, 2011; Parkes, Stein, \& Reading, 2015). These could be due to several reasons including the studentcentered nature of online courses where online courses may not have a set time for class meetings. Instead, students have to manage their time by balancing other priorities such as work and family.

Low ratings on "Use synchronous technologies" and "Asking classmates for support" The two lowest communication competencies were "Use synchronous technologies to communicate" and "Ask classmates for support." This was consistent with their ratings on importance. Students not only considered these competencies to be the lowest in terms of importance, but they also rated them lowest in terms of their confidence. More and more online programs are offering asynchronous courses to provide the online learner with flexibility by not requiring them to join synchronous meetings. In addition to time challenges, the technical challenges, and network issues of theirs and peers might have made them rate this item low.

Similar to the importance category, students rated "Asking classmates for support" low in terms of their confidence. Students in online courses may not always be provided the option to interact with their peers as some courses are still designed to be self-paced, and this could have made them rate it low. Also, this could have been because if they needed support or clarification, online students might have reached out to their instructors and not to their peers. Due to the distance involved in online learning where they may not have opportunities to interact with their classmates, students may not be comfortable reaching out to their peers for support.

\section{Demographic Factors and Student Perception}

There were no differences found when examining differences in gender, undergraduate/ graduate status, academic major (education degree compared to a non-education degree), age, and the number of online courses. This shows the students in 2018 were equal in most of these areas irrespective of the demographic differences. However, significant differences were found in race and course format.

Race. White students considered online student attributes and technical competencies to be important, whereas non-white respondents rated communication competencies to be more important. These responses could be based on student experiences and different findings show that it is essential to understand racial and cultural differences when teaching online. The white students did not think communication skills were as important as the non-white students. Previous research has found that African-American pharmacy students rated themselves lower on communication apprehension compared to white and Asian students (LaRochelle, \& Karpinski, 2016). Different communication strategies that enhance and prepare online learners of different races to communicate effectively should be considered across all races.

Course Format. Students who take the course in blended format rated online student attributes and communication competencies higher than the asynchronous or synchronous student respondents. Since these students have been exposed to a model other than entirely online, the 
blended model they might see the value in the different attributes such as being self-disciplined, setting goals as important attributes for online readiness compared to the students who have not taken blended courses. They also rated the communication competencies higher as they probably see differences in communication in blended and asynchronous/synchronous communication.

\section{Implications}

This study has several implications. The findings from this study inform faculty and instructional designers, administrators, and online students. The findings support the administration of a readiness survey to identify student needs in online learning. The results of this study and future administration of the readiness survey have implications for the design of online courses and informs both faculty teaching online courses as well as instructional designers who support faculty in the design of the courses to help students prepare for online learning. The findings also inform training and assessment development. The results of this study inform student orientation and training development for online students. Administrators can benefit from the results to support training initiatives for online students. Students should be encouraged to reflect on their attributes as an online learner, their time management, communication, and technical skills. It is crucial for students to be prepared in all these four areas. Finally, this study adds to the research base on student online readiness competencies.

\section{Limitations and Future Research}

There were some limitations to this study. First, an exact response rate could not be calculated because several program directors who distributed the survey did not provide the number of students receiving this survey. Second, the majority of the students were from Education, with very few students from other disciplines. Third, the findings from this study are based on the self-reported survey data. Due to this, there might be response bias which is the tendency of the respondent to provide inaccurate responses that are socially acceptable. Finally, the instrument does not include an exhaustive list of student online readiness competencies. It is vital to interpret the results with caution as it may not be generalizable to all contexts and settings.

Future research studies could use this SROL instrument to measure student readiness in various contexts. Future validation studies of the instrument will also be beneficial to confirm if the instrument measures online learner readiness as designed and discriminates among those students who are ready and those who are not ready. In addition, future research could investigate reasons why students view communication as the least important competency required for online learning. Specifically, future research could examine why students' confidence is low in asking for support from their peers as well as the use of synchronous technologies. Future research should strive to include other areas of competencies not included in this study and also collect data from non-education students. 


\section{References}

Allen, I. E., \& Seaman, J. (2017). Digital Compass Learning: Distance Education Enrollment Report 2017. Babson Survey Research Group. https://onlinelearningsurvey.com/reports/digtiallearningcompassenrollment2017.pdf

Bernard, R. M., Brauer, A., Abrami, P. C., \& Surkes, M. (2004). The development of a questionnaire for predicting online learning achievement. Distance Education, 25(1), 31-47. doi: $10.1080 / 0158791042000212440$

Biner, P. M., Dean, R. S., \& Mellinger, A. E. (1994). Factors underlying distance learner satisfaction with televised college-level courses. American Journal of Distance Education, 8(1), 60-71. doi: $10.1080 / 08923649409526845$

Boyd, D. (2004). The characteristics of successful online students. New Horizons in Adult Education, $18(2), 31-39$.

Caprara, G., Vecchione, M., Alessandri, G., Gerbino, M., Barbaranelli, C., \& Caprara, G. (2011). The contribution of personality traits and self-efficacy beliefs to academic achievement: A longitudinal study. British Journal of Educational Psychology, 81(1), 78-96. doi: 10.1348/2044-8279.002004

Chang, M., \& Ho, C. (2009). Effects of locus of control and learner-control on web-based language learning. Computer Assisted Language Learning, 22(3), 189-206.

Cigdem, H., \& Yildirim, O.G. (2014). Effects of students' characteristics on online learning readiness: A vocational college example. Turkish Online Journal of Distance Education, 15(3), 80-93.

Cho, M., \& Shen, D. (2013). Self-regulation in online learning. Distance Education, 34, 290-301.

Colorado, J. T., \& Eberle, J. (2010). Student demographics and success in online learning environments. Emporia State Research Studies, 46(1), 4-10

Deng, L., \& Tavares, N. (2013). From moodle to Facebook: Exploring students' motivation and experiences in online communities. Computers \& Education, 68, 167-176. doi: 10.1016/j.compedu.2013.04.028

Discenza, R., Howard, C., \& Schenk, K. (2002). The design \& management of effective distance learning programs. Idea Group Publishing.

Dray, B.J., \& Miszkiewicz, M. (2007). The intersection of learner characteristics and technology capabilities: Implications for online learning [Paper presentation]. 2007 AERA Annual Meeting, Chicago, IL, United States.

Farid, A. (2014). Student online readiness assessment tools: A systematic review approach. Electronic Journal of e-Learning, 12(4), 375-382.

Fogerson, D. L. (2005). Readiness factors contributing to participant satisfaction in online higher education courses [Unpublished doctoral dissertation]. University of Tennessee, Knoxville.

Garrison, D. R., Cleveland-Innes, M., \& Fung, T. (2004). Student role adjustment in online communities of inquiry: Model and instrument validation. Journal of Asynchronous Learning Networks, 8(2), 61-74.

Gore, P. A. (2006). Academic self-efficacy as a predictor of college outcomes: Two incremental validity studies. Journal of Career Assessment, 14, 92-115. 
Hew, K. F., \& Cheung, W. S. (2008). Attracting student participation in asynchronous online discussion: a case study of peer facilitation. Computers \& Education, 51(3), 1112-1124.

Ho, L., Tsung-Hsien, K., \& Binshan, L. (2010) Influence of online learning skills in cyberspace. Internet Research, 20(1), 55-71. doi: 10.1108/10662241011020833

Hung, M. L., Chou, C., Chen, C. H., \& Own, Z. Y. (2010). Learner readiness for online learning: Scale development and student perceptions. Computers \& Education, 55(3), 1080-1090.

Islam, A. N. (2012). Understanding e-learning system usage outcomes in hybrid courses. In 2012 45th Hawaii International Conference on System Sciences (pp. 118-127). IEEE. doi: 10.1109/HICSS.2012.613

Johnson, G. (2019). On-campus and fully-online university students: Comparing demographics, digital technology use and learning characteristics. Journal of University Teaching and Learning Practice, 12(1), 15.

Kaymak, Z., \& Horzum, M. (2013). Relationship between online learning readiness and structure and interaction of online learning students. Kuram ve Uygulamada Egitim Bilimleri, 13(3), 1792 1797. doi: $10.12738 /$ estp.2013.3.1580

$\mathrm{Ke}, \mathrm{F} \& \mathrm{Xie}, \mathrm{K}$. (2009). Toward deep learning for adult students in online courses. Internet and Higher Education, 12, 136-145

Ke, F. (2010). Examining online teaching, cognitive and online presence for adult students. Computers \& Education, 55, 808-820.

Kerr, M. S., Rynearson, K. \& Kerr, M. C. (2006). Student characteristics for online learning success. Internet and Higher Education, 9, 91-105.

Kummerow, A., Miller, M., \& Reed, R. (2012). Baccalaureate courses for nurses online and on campus: A comparison of learning outcomes. American Journal of Distance Education, $26(1), 50-65$

LaRochelle, J. M., \& Karpinski, A. C. (2016). Racial differences in communication apprehension and interprofessional socialization in fourth-year doctor of pharmacy students. American Journal of Pharmaceutical Education, 80(1), 8.

Lin, B., \& Hsieh, C. T. (2001). Web-based teaching and learner control: A research review. Computers \& Education, 37(4), 377-386.

Liu, Y., Lavelle, E., \& Andris, J. (2002). Experimental effects of online instruction on locus of control. United States Distance Learning Association Journal, 16(6).

Mattice, N. J., \& Dixon, P. (1999). Student preparedness for distance education (ED 436 216). College of the Canyons.

Martin, F., \& Parker, M.A. (2014). Use of Synchronous Virtual Classrooms: Why, Who and How? MERLOT Journal of Online Learning and Teaching, 10(2), 192-210.

Martin, F., \& Bolliger, D.U. (2018). Engagement matters: Student perceptions on the importance of engagement strategies in the online learning environment. Online Learning Journal, 22(1), $205-222$.

Martin, F., Wang, C., \& Sadaf, A. (2018). Student perception of helpfulness of facilitation strategies that enhance instructor presence, connectedness, engagement and learning in online courses. The Internet and Higher Education, 37, 52-65. 
McGhee, R. H. (2010). Asynchronous interaction, online technologies self-efficacy and selfregulated learning as predictors of academic achievement in an online class. (Accession No. 3453755) [Doctoral dissertation, Southern University and Agricultural and Mechanical College]. Retrieved from ProQuest LLC.

McKavanagh, C., Kanes, C., Beven, F., Cunningham, A., \& Choy, S. (2002). Evaluation of webbased flexible learning (ED 462 604). National Centre for Vocational Education Research. https://www.ncver.edu.au/_data/assets/file/0011/10280/evaluation-web-basedflexible-learning-750.pdf

McVay, M. (2001). How to be a successful distance learning student: Learning on the Internet. Prentice Hall.

Michinov, N., Brunot, S., Le Bohec, O., Juhel, J., \& Delaval, M. (2011). Procrastination, participation, and performance in online learning environments. Computers \& Education, 56(1), 243-252.

Moore, M. G. (2013). Handbook of distance education (3rd ed.). Routledge.

Muse, H. E. (2003). The web-based community college student: An examination of factors that lead to success and risk. The Internet and Higher Education, 6, 241-261. doi:10.1016/S10967516-(03)00044-7

Osborn, V. (2001). Identifying at-risk students in videoconferencing and web-based distance education. The American Journal of Distance Education, 8(1), 47-63.

Park, J., \& Wentling, T. (2007). Factors associated with transfer of training in workplace e-learning. Journal of Workplace Learning, 19(5), 311-329. doi: 10.1108/13665620710757860

Park, Y. J., \& Bonk, C. J. (2007). Synchronous learning experiences: Distance and residential learners' perspectives in a blended graduate course. Journal of Interactive Online Learning, $6(3), 245-264$.

Parkes, M., Stein, S., \& Reading, C. (2015). Student preparedness for university e-learning environments. The Internet and Higher Education, 25, 1-10.

Parnell, J. A., \& Carraher, S. (2002). The role of effective resource utilization in strategy's impact on performance. International Journal of Commerce and Management, 13(3), 1-34.

Prior, D. D., Mazanov, J., Meacheam, D., Heaslip, G., \& Hanson, J. (2016). Attitude, digital literacy and self efficacy: Flow-on effects for online learning behavior. The Internet and Higher Education, 29, 91-97.

Quinn, F. (2011). Learning in first-year biology: Approaches of distance and on-campus students. Research in Science Education, 41, 99-121.

Rollnick, S., Mason, P., \& Butler, C. C. (2010). Health Behavior Change E-Book. Elsevier Health Sciences.

Roper, A. R. (2007). How students develop online learning skills. Educause Quarterly, 30(1), $62-64$.

Shi, J., Chen, Z., \& Tian, M. (2011). Internet self-efficacy, the need for cognition and sensation seeking as predictors of problematic use of the Internet. Cyber Psychology, Behavior and Social Networking, 14(4), 213-234.

Simon, M. K., \& White, J. (2013). Survey/interview validation rubric for expert panel-VREP. http://dissertationrecipes.com/wp-content/uploads/2011/04/Expert-Validation-v3.pdf 
Smith, P. J. (2001). Learning preferences of TAFE and university students. Australian and New Zealand Journal of Vocational Education Research, 9(2), 87-109.

Smith, P. J. (2005). Learning preferences and readiness for online learning. Educational Psychology: An International Journal of Experimental Educational Psychology, 25(1), 3-12.

Smith, P. J., Murphy, K. L., \& Mahoney, S. E. (2003). Towards identifying factors underlying readiness for online learning: An exploratory study. Distance Education, 24(1), 57-67.

Tsai, M. J., \& Tsai, C.C. (2003). Information searching strategies in web-based science learning: The role of Internet self-efficacy. Innovations in Education and Teaching International, 40(1), $43-50$.

Toppin, I. N., \& Toppin, S. M. (2016). Virtual schools: The changing landscape of K-12 education in the U.S. Education and Information Technologies, 21(6), 1571-1581.

U.S. Department of Education. (2014). 2003-04, 2007-08, and 2011-12 National Postsecondary Student Aid Study. https://nces.ed.gov/programs/digest/d16/tables/dt16_311.22.asp?current=yes

U.S. Department of Education. (2018). Digest of Education Statistics, 2016 (NCES 2017-094), Table 311.15. https://nces.ed.gov/fastfacts/display.asp?id=80

Wang, A. Y., \& Newlin, M. H. (2002). Predictors of web-student performance: The role of selfefficacy and reasons for taking an on-line class. Computers in Human Behavior, 18, 151163.

Warner, D., Christie, G., \& Choy, S. (1998). Readiness of VET clients for flexible delivery including on-line learning. Australian National Training Authority.

Watkins, R., Leigh, D., \& Triner, D. (2004). Assessing readiness for online learning. Performance Improvement Quarterly, 17(4), 66-79.

$\mathrm{Yu}, \mathrm{T}$. (2018). Examining construct validity of the student online learning readiness (SOLR) instrument using confirmatory factor analysis. Online Learning, 22(4), 277-288. doi: 10.24059/olj.v22i4.1297

Yu, T., \& Richardson, J. (2015). An exploratory factor analysis and reliability analysis of the student online learning (SOLR) instrument. Online Learning, 19(5), 120-141.

Zimmerman, W. A., \& Kulikowich, J. M. (2016). Online learning self-efficacy in students with and without online learning experience. American Journal of Distance Education, 30(3), 180191. 